\title{
LITERATUROZNAWSTWO
}

\author{
TATIANA KROL
}

\section{The literary expression of national trauma in Irish and Ukrainian literatures}

\author{
Отражение национальной травмы \\ в ирландской и украинской художественной литературе
}

\begin{abstract}
The most tragic and traumatic experiences in the respective histories of Ireland and Ukraine were their Great Famines. This paper discusses literary techniques used for the expression of national trauma in Irish and Ukrainian famine fictions. It examines the representations of An Gorta Mór and the Holodomor in The Silent People by Walter Macken, The Hungry Land by Michael Mullen, Maria: A Chronicle of a Life by Ulas Samchuk and Sweet Snow by Alexander J. Motyl, and demonstrates that the rhetoric of a national character occupies a prominent position in the novels. Exploring images of the Self and the Other within the oppressor/oppressed dichotomy, expressed from the perspective of the latter, the paper argues that national character stereotypes function to highlight the detrimental effects of British rule in Ireland and Soviet rule in Ukraine. Imagology and trauma studies underpin the paper's theoretical framework. The paper is part of the doctoral thesis An Imagological Study of the Depiction of the Irish and Ukrainian Great Famines in the novels by Samchuk, Macken, Motyl and Mullen, supervised by Dr. Brigitte Le Juez and Dr. Áine McGillicuddy, defended in December 2018 at Dublin City University.
\end{abstract}

Keywords: An Gorta Mór, the Holodomor, images of Self and the Other, famine, trauma

Tatiana Krol, Dublin City University, Dublin - Ireland, tatianakrol5@gmail.com, ORCID ID: https://orcid.org/0000-0001-8410-7996

The literature of a nation is far more revealing than all the official histories ever written

(Broderick quoted by Gunilla Bexar 1)

Both the Irish and Ukrainian people endured appalling moments in the histories of their countries, 'horrendous' events that have left 'indelible marks upon their consciousness', and marked their memories (Alexander, Eyerman, Giesen, 
Smelser, and Sztompka 1). Between 1845 and 1852, Ireland experienced one of the most devastating calamities in her history - the Great Famine known as An Gorta Mór. In a country with a population of 8.2 million people before the famine, deaths in the famine years ranged from 290,000 to $1,500,000$, while another 1.5 million people emigrated (Travel Through the Ireland Story, electronic source). Highlighting the scale of the Irish Great Famine, Terry Eagleton has called it "the greatest social disaster of 19th century Europe - an event with something of the characteristics of a low-level nuclear attack" (Kelly 2).

The Holodomor was a famine that ravaged Ukraine in 1932-1933, having taken from 3.5 up to 10 million lives, according to various data sources. The term 'Holodomor' is the combination of the two Ukrainian words, 'holod' and 'mor', meaning 'death by starvation'. Raphael Lemkin, the author of the term 'genocide', explained in his article Soviet Genocide in the Ukraine (1953) why he considered Ukraine's 1932-1933 Famine a case of genocide. He described it as "the mass murder of peoples and of nations that has characterized the advance of the Soviet Union into Europe", highlighting that it was "the classic example of Soviet genocide, its longest and broadest experiment in Russification - the destruction of the Ukrainian nation" (Lemkin 31). Research on these two national tragedies, the Irish and Ukrainian, reveals points that can be examined in juxtaposition with each other.

The scale of these famines indeed allows a comparison: their death toll mounted to one-quarter of the population of each country. Both famines had dramatic effects on the Irish and Ukrainian people within each country and on those who fled their homes. Another important aspect of similarity is that at the time of the famine both countries were parts of empires. The fact that the famines' magnitude was a result of the British rule in Ireland and Soviet rule in Ukraine has had a significant impact on the issue of culpability. Even though the Great Famine in Ireland was caused by a natural factor - the potato blight - British misrule and lack of concern in Westminster for its colony led to immense losses. Discussing Ireland's famine, the terms 'British' and 'English' are often used interchangeably, highlighting that the English were the domineering nation in the British Empire. In a similar manner, the terms 'Soviet' and 'Russian' have become synonymous in the Ukrainian discourse. Ukraine's 1932-1933 Famine was entirely politically engineered by the Soviet government in Moscow. It is not surprising, therefore, that accountability is central in literary representations of An Gorta Mór and the Holodomor, for British and Soviet government policies were seen as those that have brought about suffering and death. Michael Nicholson's reflection on Ireland's Great Famine accentuates its magnitude: "«A million dead. A million fled». It was those few words that had such an impact on me. Think of it. Try to visualise. Try putting it into a modern context, something happening today, something you 
are watching on television news, an apocalyptic disaster on an unheard-of scale, something that dwarfs Hiroshima" (Famine novel changed my mind on England's guilt, electronic source). Timothy Snyder reminds us that the Holodomor was "one of the most harrowing passages in the recent literature on Europe's dark twentieth century" (Roche 48).

Irish and Ukrainian famine fictions draw heavily on the political, ideological and economic reality revealing the historical conditions in which the famines occurred. In doing so, they reproduce the power tensions and relationships between the victimized and perpetrators, highlighting that the blame is on the latter, and can be seen as "yet another modality for sharing trauma" (Kaplan 101). In this regard, it is important to note that the Self/Other process is a two-way phenomenon. The English perception of the Irish Otherness in pre-famine and famine periods is illustrative of this. In his analysis of the construction of the Irish image in the British press, Michael de Nie presents multiple passages portraying the Irish from newspapers and magazines that circulated prior to and during An Gorta Mór, such as this one, published in The Times:

They have come amongst us, but they have not become of us. They have earned our money; but they have carried back neither our habits nor sympathies, neither our love for cleanliness nor our love for comfort, neither our economy nor our prudence. Is this distinctive character incapable of subjugation or change? (de Nie 90)

De Nie provides many more examples of unfavourable descriptions of the Irish and points out that their stereotypical representations as ignorant, uncouth, dirty, immoral and lazy were a dominant trend in nineteenth-century British press. The Irish peasant was depicted as 'violent' and 'conspiring' (de Nie 90), a 'wild man', 'an animal in human form' (de Nie 120), 'short-sighted and foolish' (de Nie 121), and often 'symbolized in the satirical press by the pig' (de Nie 17, 233). This view is reflected in the famine fiction. One of Walter Macken's characters, a tithe proctor, Clarke, for example, sees benefits in the famine: "When it was all over, it would be a tranquil country. It would have been cleansed of the parasites. Things would be ordered, like a good estate" (Macken 328). Paul Martin Lester's thoughts on stereotyping suggest that it exerts crucial influence on the relations between groups of people, while at the same time highlighting the role of power in the process of stereotype formation: "History has shown that stereotyping can lead to scapegoating, which can lead to discrimination, which can lead to segregation, which can lead to physical abuse, which can lead to state-sponsored genocide" (Lester, Ross 2). The Holodomor is another example that endorses this point.

In Soviet Ukraine in the 1930s, the quality of Otherness was largely ascribed to the peasantry. Wealthy peasants were labelled as 'kulaks', branded as traitors and portrayed as 'the enemy of the people'; and these images were abundant in 
the Soviet press. The term 'kulak' was used to identify the enemy, and "the term «de-kulakization» was shorthand for the "elimination of the kulaks as a class»" (Applebaum 124). When they were eliminated, the term shifted to denote less wealthy ones, and eventually extended to mean all those who opposed the Soviet regime. Anne Applebaum explains that:

in 1929, just as in 1919, the notion of a "wealthy" peasant remained a relative thing. In a poor village, "wealthy" could mean a man with two pigs instead of one. A "wealthy" peasant might also be one who inspired dislike or envy among his neighbours - or who acquired enemies among the village rulers or the local communists (Applebaum 124).

Negative attitudes towards peasants are mirrored in Ukrainian famine fiction. One of Alexander J. Motyl's characters, Vanya, dismisses peasants: "Eta tolka kulak" [...] "It's only a kulak" (Motyl 45). His contempt is expressed both in words: "There are many rich peasants hiding from Soviet power under the snow" [...] "That's where they belong, svoloch.", and in deeds: "Did I ever tell you about the kulaks in my village? We took their grain and their clothes and we drove them bare-assed to the cemetery" (Motyl 45-46).

In both cases, the "othering" process, based on stereotyping, is entwined with the issue of power, which, within a colonial context, serves the colonizer to "justify the colonial system" that is achieved by "a systematic devaluation of the colonized" (Memmi 110). Seamus Deane's observation substantiates the interdependence between stereotyping and power: "The definition of otherness, the degree to which others can be persuasively shown to be discordant with the putative norm, provides a rationale for conquest" (Deane 12). In line with Manfred Beller's point that valorizing the Other is "nothing but a reflection of one's own point of view" (Beller 6). Irish and Ukrainian famine novels show the reciprocity of the "othering" process. Their representations of the Other during An Gorta Mór and the Holodomor respectively are constructed upon negative perceptions of the famines' perpetrators. The "othering" process is, therefore, reversed, and the nation exercising the power is Othered. Experiencing a traumatic event essentially generates a sense of anger and outrage, which, in turn, results in ascribing negative traits to the Other. In this way, the colonized deconstruct their Otherness. Within the Irish and Ukrainian contexts, the "othering" process, caused by the famines, is deepened by the awareness of the two nations' long-term colonial oppression throughout hundreds of years prior to the famine events. The stereotypes of the past continue to circulate; moreover, they grow stronger if power issues, the force that fuels the stereotypes, have not been resolved.

1 The Russian word “сволочь" can be translated as "asshole" or "scum". 
In The Silent People, The Hungry Land, Maria: A Chronicle of a Life and Sweet Snow, images are deployed for the expression of national trauma. At the core of the novels' imagological constructs are images of the Self representing the group of victims, and images of the Other symbolic of the group of perpetrators. Within this binary opposition, the rhetoric of a national character functions to draw a line of distinction between them. The Irish and Ukrainian texts abound in national character stereotypes in their representations of the Irish and English, and Ukrainians and Russians respectively. The dichotomic constructs English/Irish and Russian/Ukrainian are formed on opposing qualities, and a positive image of the Self contrasts with a negative portrayal of the Other. Characters belonging to the group of the Self are imbued with favourable traits, such as, diligence, kindness, sense of humour, spirituality and love of the land. Traits characteristic of the Other are laziness and cruelty.

In Maria: A Chronicle of a Life, Samchuk presents his characters, Ukrainian country people, as hard-working and religious. They adhere to religious customs that encompass their work and leisure, and lead a peaceful life in Hnyloryby - "the ancient spreading village" that "has entwined itself intricately around orchards, meadows, and ravines" (Samchuk 39). The protagonists' love to God parallels their reverent attitude to the land:

Martyn scatters the white kernels, and Maria walks behind him and shoves the tiny seeds into the crumbly soil. The billowing of the tolling bell swoops down over them, and Martyn pauses, doffs his grimy cap, and blesses himself three times with a wide, sweeping motion. Maria also blesses herself... (Samchuk 38)

The Ukrainian characters' love for their native land can be compared to the portrayal of patriotism in the Irish novels. In Macken's The Silent People and Mullen's The Hungry Land, this trait is used to separate the Self from the Other. The Irish are depicted as patriots, even those living abroad. Old Mr. Prendergast, for example, "never deviated from his love of Ireland" (Mullen 32). In the context of British colonial rule, the patriotism of the Irish is regarded as nationalism by the English. This is clearly shown in The Silent People, whose characters, Daniel O Connell, Cuan, and others, are portrayed as Ireland's patriots and perceived by the English as criminals. The theme of patriotism allows highlighting how unjust British rule and cruel treatment of the Irish add to the rise of the nationalist spirit in Ireland. This is validated by Dualta's reflection that "There comes a time when oppression becomes too hard to bear" [...] "and men must assert themselves" (Macken 229).

These two thought-provoking concepts, patriotism and nationalism, are also part of the Self-image in Motyl's Sweet Snow. His protagonists' identities: they are all of different nationalities, reveal the complexity of its construction. One 
of the elements that unites them is their love of their native land. German aristocrat and diplomat, Count August von Mecklenburg, cultural attaché at the Polish consulate, Zbigniew Pieracki, and a poet of Ukrainian origin from Vienna, Igor Kortschenko, are at variance in many ways due to political and ideological issues between their countries, yet they are all ardent patriots of their countries. The Pole is proud of his feeling for his Motherland: "You must know that I would die for Poland. All Polish patriots would. You must know that, too" (Motyl 111). Von Mecklenburg's deep love for his native land is felt in the "unconcealed grief" with which the count speaks of a Germany devastated by the war, and her "ill-tempered fortuna", as well as in his determination to be useful to his country "at its time of greatest need" (Motyl 98). Pieracki's and von Mecklenburg's love of their countries echoes Kortschenko's yearning for an independent Ukraine during this tragic time in history, and their feelings allow readers to see the ambiguity of the concepts of nationalism and patriotism. Moreover, reflections on the characters' suffering and their countries' plight sharpen readers' awareness that the Bolshevik rule was brutal and destructive. In this way, a deeper connection between the literary characters and readers is created, adding a sense of credibility to the former and arousing empathy in the latter.

Credibility is important in famine fiction. Frequent use of geographical names, numerous references to actual events and historical figures, as well as realistic descriptions of famine victims, found in all four novels, approximate the fictional texts to factual accounts, making the "realness of their existence" more convincing (The Rise of the Nameless Narrator, electronic source). This is especially true in the case of the Ukrainian novels whose graphic scenes of suffering and death reflect witnesses' testimonies recorded in 1932-1933. ${ }^{2}$ The fact that famine fiction mirrors real accounts in its representations of cruelty makes the image of the Other look even more odious. In Sweet Snow, the ruthlessness of the Soviet regime is heightened by the elements of spatiality and disgust. The magnitude of the characters' plight increases with the enlargement of the novel's spatial entities: the protagonists experience more pain and suffering as they move from small to bigger places. This strategy allows for the development of the reader's feelings of empathy for the famine victims and condemnation of the cruelty of the per-

\footnotetext{
2 See, for example, Yuriy Mytsyk. Ukrainian Holocaust 1932-33. Eyewitness Accounts of Those Who Survived: Part One; Ганна Капустян. Пам'ять 33-го Кличе Молодих. Сповіді свідків і слово історика; 'Testimonies of the Witnesses of the Holodomor' - [my translation]. Padio Cвобода, Radio Svoboda Ukrainian Service, Web. 23.11.2013. http://www.radiosvoboda.org/media/ video/25177973.html; Ярослава Трегубова. 'Свідок Голодомору Станіслав Ільницький: померлих ніхто не закопував' ['The Holodomor Witness Stanislav Ilnytskyy: nobody covered over the graves with the dead' - my translation]. Padio Свобода. Radio Svoboda Ukrainian Service. Web. 22.11.2017. https://www.radiosvoboda.org/a/28870173.html.
} 
petrators. The descriptions of those who perished from hunger are particularly disturbing:

Five minutes later, they chanced upon a bloated corpse lying face up in the ice. It was a girl, no more than fifteen years old, with coal-black hair tied in two braids and a sack-like beige dress made of some coarse material. She was barefoot and her arms lay along her sides, with the palms of her small hands facing upward near the surface of the ice. Her gaunt yellow face had remained well preserved: she had green eyes, long lashes, and what must have at some time been full lips. Only the tip of her nose, which extended above the ice, had begun to rot, creating an unsettling effect that reminded the count of a painting by Kirchner or Dix (Motyl 59).

The horror of the famine is deepened by the Bolsheviks' cruel deeds:

Four meters away stood the iconostasis, its gold frames glistening darkly and its painted icons almost invisible to the eye. Hanging from the three crosses, evenly arrayed along the top of the iconostasis, were three emaciated bodies. The nooses had been attached to the crosses. The central figure, with long white hair and a long white beard and dressed in a black cassock, was obviously the village priest. The other two were probably village elders or kulaks. Their heads were tilted to the sides, their glassy eyes bulged, as if they were surprised by their own death, and their blackened tongues extended from their distorted mouths to their pointy chins. Their hands were tied behind their backs and their bare feet, bloody and swollen, dangled below (Motyl 145).

The images of those who have perished from hunger, shown side by side with the cruelty of the Other, enhance understanding of the Bolsheviks' culpability for the famine.

Although cruelty is also shown as the most prominent trait of the Other in the novels by Macken and Mullen, the scenes depicting it appear less severe than in the texts by Samchuk and Motyl. The Silent People's most dramatic episode is the execution of two Irish men, "a double hanging" (Macken 65). Their death arouses readers' condemnation of British rule, for those who are hanged are innocent. Yet the scene of hanging is not presented in such distressing details as the descriptions of death in Motyl's passages: "The living ones fell and the bodies swung, and there were still tears on Paidi's dead cheeks when Dualta turned away and groped his way free of the square and stumbled down the street" (Macken 66). And in The Hungry Land, one of the most egregious examples of cruelty is when Colonel Spiker orders that the "half-idiot" (Mullen 56) and "simpleton" (Mullen 66) Ned Kenny be whipped a hundred times. It can be suggested that Soviet rule and the Holodomor organizers are associated with a higher degree of premeditated violence. ${ }^{3}$ The fact that Ukraine's $1932-33$ Famine is a more recent event probably adds to the way it is represented in literary works: with particularly harsh and

${ }^{3}$ On Bolshevik policies in Ukraine see Volodymyr Vassylenko. The Holodomor: An Act of Genocide against the Ukrainian People of 1932-1933; Anne Applebaum. Red Famine; Lesa Melnyczuk. Silent 
more realistic portrayals of its perpetrators. This point can be corroborated by Stanislav Kulchytsky's point that more recent events are likely to show a larger degree of politicization:

No one is crossing swords over the revolution of 1905-1907, and its centennial is passing completely unnoticed. The situation with the Holodomor or the problem of the OUN and UPA are different because they are part of the life experiences of the current generation of Ukrainian citizens, who were participants in those events, or the children of these people. People tend to have differing opinions on events in the not so distant past, whereas all politicians try to please the public (Why did Stalin exterminate the Ukrainians?, electronic source).

A sense that the main focus in Ukrainian famine fiction is on the cruelty of the Other is revealed in the novels' endings. In Maria: A Chronicle of a Life, the protagonist dies of hunger: "The moon is slowly fading. One after the other, thoughts vanish from her head never to return. Her eyes grow heavy and slowly close. Her dry lips. Turn cold... Her chest caves in... The last nerve is tensely severed. Her heart beats one last time" (Samchuk 241). In Sweet Snow, all four protagonists starve to death. Their passing conveys the meaning of the demise of the entire country: "There was nothing here. Everything was dead, rotten, and decaying and everyone was dead, rotten, and decaying. Ukraine - his Ukraine - was dead, a corpse. No, it was worse. It was gone. It had disappeared, vanished. It had been extinguished and obliterated by the Russians" (Motyl 147). By contrast, most of the Irish characters survive the famine, and the Irish novels' endings adopt a more hopeful stance. The Silent People ends with the protagonist's expression of his beliefs in the future: "Then there is no fear for us, or for my son" said Dualta. "We will survive" (Macken 346). The Hungry Land's protagonists emigrate to America, and the novel ends with an expectation of a new life: "The stars were bright in the wide arc of the heavens. A wind was rising in the sails" (Mullen 429). The final passages from the novels on the Holodomor are devoid of hope.

Importantly, the dynamics of the literary construct of the Other throughout the novels is reinforced by a cultural difference - the use of language. Travis Hubbs's explanation of the importance of the language for a national identification suggests its suitability in distinguishing between the Self and the Other:

The conceptual existence of either nation, of course, depends on the language that conveys it. [...] Identity functions through language and, in turn, language functions through a negative structure of semiotic comparisons and contrasts. In other words, identity can only exist alongside its opposite (Hubbs 1-2).

Memories. Traumatic Events; Serhii Plokhy. The Gates of Europe. A History of Ukraine; Yuri Mytsyk. Український голокост. 1932- 1933: Свідчення тих, хто вижив and other sources. 
Corroborating the view that the descriptions of the Holodomor events are stark, it should be pointed out that in the Ukrainian novels, the language of the Other acquires a decidedly negative connotation. In fact, it comes to denote the Other with idleness and the use of bad language, indicating the stereotypical Russian. In this way, clear-cut patterns of the Ukrainian Self-image and the Russian Other are formed. In Macken's and Mullen's novels, the Irish language also constitutes an important attribute of the Self; however, English as a language is not depicted as essentially disadvantageous. The idea of the importance of education, also in English, is demonstrated in the themes on literacy, learning, and schooling throughout The Silent People and The Hungry Land.

In addition, a juxtaposition of the themes of hybridity in the Irish novels and disintegration in the Ukrainian ones stresses the sharpness of the famine representations in the latter. Hybrid images in Macken's and Mullen's works mark the process of a transition between the Self and the Other; and, depending on the dichotomous qualities of humanity and cruelty, they can belong to either one of them. Samchuk's characters that undergo the process of disintegration are those that move from the group of the Self to the group of the Other, and they are depicted in an ultimately negative light. In Motyl's Sweet Snow, the characters perpetrating cruelty comprise the group of the Other, while their victims constitute the Self. Hence, Otherness is based on cruelty, and it is associated with the imposition of power.

This brief analysis of representations of An Gorta Mór and the Holodomor in The Silent People by Walter Macken, The Hungry Land by Michael Mullen, Maria: A Chronicle of a Life by Ulas Samchuk and Sweet Snow by Alexander J. Motyl demonstrated that the rhetoric of a national character occupies a prominent position in the novels. Reproducing the Anglo-Irish and Russian-Ukrainian power tensions and relationships during An Gorta Mór and the Holodomor, images of the Self and the Other are deployed to highlight the detrimental effects of the British rule in Ireland and the Soviet rule in Ukraine. Within the context of the unjust and oppressive conditions for Ireland and Ukraine, violence and cruelty are the main gauge of the "othering" process; however, cultural elements prove to be the most convenient and easily accessible tools for the discernment of the Self from the Other.

John Broderick pointed out that (a country's) literature is more revealing than all official histories. Indeed, in literature, factual material is interwoven with characters' actions and perceptions that reflect various, often antagonistic, views and attitudes. This allows us as readers to see a broader picture of events and historic processes and understand the reasons behind them. 


\section{Bibliography}

Alexander, Jeffrey C., Ron Eyerman, Bernard Giesen, Neil J. Smelser, Piotr Sztompka. Cultural Trauma and Collective Identity. Berkeley, CA, University of California Press, 2004.

Applebaum, Anne. Red Famine: Stalin's War on Ukraine. London, Penguin Books, 2017.

Bell, Duncan, ed. Memory, Trauma and World Politics: Reflections on the Relationship between Past and Present. Basingstoke, United Kingdom, Palgrave Macmillan, 2010.

Beller, Manfred. "Perception, Image, Imagology". Imagology. The Cultural Construction and Literary Representation of National Characters: A Critical Survey. Ed. Manfred Beller, Joep Leerssen. Amsterdam-New York, Rodopi, 2007.

Bexar, Gunilla. The Great Irish Famine in History-Writing and Prose Fiction: "The Mutual Interplay of Two Narrative Genres". Åbo, Åbo Akademi University Press, 2016.

Collins, Michael. "Famine fiction and a surfeit of facts". The Irish Times. Web. 29.03.2017. www. irishtimes.com/culture/books/famine-fiction-and-a-surfeit-of-facts-1.3029213.

De Nie, Michael. The Eternal Paddy: Irish Identity and the British Press. Madison, WI, University of Wisconsin Press, 2004.

Deane, Seamus. "Introduction”. Nationalism, Colonialism and Literature. Ed. Terry Eagleton, Frederic Jameson, Edward Said. Minneapolis-London, University of Minnesota Press, 1990.

Donnelly, Brian. "The Great Famine and the Literary Imagination". An Irish Quarterly Review, vol. 69, no. 275/276, Autumn - Winter 1980, p. 260-272.

Hubbs, Travis. "The Consumption of Simulacra: Deconstructing Otherness in Katherine Anne Porter's Mexican Conceptual Space". Journal of Texas Women Writers, vol. 1.2, 2009, p. 1-29.

Kaplan, E. Ann. "«Translating» Trauma in Postcolonial Contexts”. Trauma Culture: The Politics of Terror and Loss in Media and Literature. New Brunswick, New Jersey-London, Rutgers University Press, 2005.

Kelly, John. The Graves are Walking: A History of the Great Irish Famine. London, Faber \& Faber, 2012.

Kulchytsky, Stanislav. "Why did Stalin exterminate the Ukrainians?". День. Web. 25.10.2005. day. kyiv.ua/en/article/history-and-i/why-did-stalin-exterminate-ukrainians-4.

Lemkin, Raphael. Soviet Genocide in Ukraine. Kyiv, Maisternia Knyhy, 2009.

Lester, Paul Martin, Susan Dente Ross, eds. Images that Injure: Pictorial Stereotypes in the Media. Westport, Connecticut-London, Praeger, 2003.

Macken, Walter. The Silent People. London, Pan Books Ltd., 1965.

Mark-FitzGerald, Emily. "Artistic works inspired by the Great Famine struggle to do it justice, but they keep the memory alive". Web. 14.11.2018. www.ucd.ie/newsandopinion/news/2018/ november/14/artisticworksinspiredbythegreatfaminestruggletodoitjusticebuttheykeepthememoryalive/.

Memmi, Albert. The Colonizer and the Colonized. London, Earthscan Publications, 1990.

Motyl, Alexander J. Sweet Snow. Somerville, Massachusetts, Červená Barva Press, 2013.

Mullen, Michael. The Hungry Land. New York-London-Toronto-Sydney-Auckland, Bantam Press, 1986.

Nicholson, Michael. "Famine novel changed my mind on England's guilt". The Irish Times, 14.12.2015. Web. 10.08.2019. www.irishtimes.com/culture/books/michael-nicholson-famine-novel-changed-my-mind-on-england-s-guilt-1.2465994.

Powell, John A. "Us vs them: the sinister techniques of 'Othering' - and how to avoid them". The Guardian. 08.11.2017. Web. 12.08.2019. www.theguardian.com/inequality/2017/nov/08/us-vs-them-the-sinister-techniques-of-othering-and-how-to-avoid-them. 
Roche, Helen. An Analysis of Timothy Snyder's Bloodlands: Europe Between Hitler and Stalin. London, Routledge, 2017.

Sacks, Sam. "The Rise of the Nameless Narrator". The New Yorker. 03.03.2015. Web. 24.10.2016. www.newyorker.com/books/page-turner/the-rise-of-the-nameless-narrator.

Samchuk, Ulas. Maria: A Chronicle of a Life. Toronto, Language Lanterns Publications Inc., 2011. Sayegh, Pascal-Yan. Cultural Hybridity and Modern Binaries: Overcoming the Opposition between Identity and Otherness? 2008. Web. 11.03.2020. https://halshs.archives-ouvertes.fr/halshs-00610753/document.

Travel Through the Ireland Story. Web. 11.03.2020. www.wesleyjohnston.com/users/ireland/past/ famine/blight.html. 
